modelled by Napoleon is rife with bureaucracy should be resisted. In reality, the government is both accessible and informal. Ministers consult interested parties, and seem to take good advice wherever they can find it. And while the law is the law, most regulations are decrees, which can be relatively easily amended.

It is nevertheless irksome, and a considerable impediment to the welfare of the research enterprise, that questions of money and of the appointment of people should habitually require reference to the centre. That people should have to travel to Paris to intercede with officials over the rejection of applications for small amounts of money is similarly humiliating and a waste of time whose value is now appreciated in France more acutely than ever. Now that devolution is under way (see page 131) cannot the Paris lawyers find a legal mechanism for behaving as if the government's researchers were honest people?

There is a particular problem over the acquisition of special skills, computer programming for example. Few such people will work in government research because they can do much better elsewhere, but laboratories cannot employ them even on short-term contracts for fear of creating illicit government positions.
And there is not enough money to purchase all the software needed from outside contractors, so that far too many researchers double up as their own programmers. Even in France, there should be a solution.

- Money. France compels admiration for the changes brought about in the past decade and more in the economy at large, not simply in research. It is now a much more prosperous country, even if there are constant envious looks across the border to the East - at West Germany. Yet the government may have underestimated the true cost of its ambitions for research.

The calculation is that no great harm may be done if salaries in the public service are so low that people can easily be tempted away to industry, but that will not be true for ever. Despite the success of schemes for adding to research spending from other sources, there is ample evidence that many able people could do much more were it not for the accentuating lack of operating costs. That, on balance, is not simply a waste of people but is potentially destructive of what must now be the most encouraging feature of French research - the generally growing general conviction that every able person can make his or her mark.

\title{
POLITICS AND SCIENCE
}

\section{Chevènement's legacy to the 90 s}

WAs Jean-Pierre Chevènement the cause of the transformation of French science in the past decade, or was he himself the product of a process already under way?

The question is still much debated, for which reason it is important that the tense in which it is asked should not be taken as a sign that Chevènement belongs to history or, worse, is dead. As minister of defence in the French government, he spent several days of last month on an aircraft carrier in the Atlantic. One day last week, with three other ministers, he was present at a passing-out parade at the national police college.

Yet there has never been a period in the recent history of the administration of French science quite like the year beginning with François Mitterrand's election as president on 10 May 1981. During the election, the Socialists had made no secret of their ambitions for research, but the reality of Chevènement's plans for increased spending were nevertheless a surprise for many people. The research budget for 1982 turned out to be 25 per cent greater than that for 1981 .

This daring leap forward had been planned in advance by a working group under the chairmanship of Professor François Gros of the Pasteur Institute. Mitterrand spelled out his policy for research at a meeting at the Luxembourg palace on the eve of the election. In the international competition for discovery, will France be at the front or the back? We may be poor in natural resources, but we are rich in grey matter. That was the point at which Mitterrand promised that research and development expenditure would be increased to 2.5 per cent of the gross domestic product by 1985 - a promise subsequently written into law.

Chevènement's energy and enthusiasm seem to have been crucial. Gros has told how, soon after the election, he had visited Chevènement to explain that, whatever else was done, "the first essential is to change the relations between people" in research; his fear was that the imposition of new structures and tasks on a research community already disillusioned by neglect would bring further alienation. Why, he asked, not organize a great national colloquium at which these issues could be argued out?

The notion was not entirely novel; in 1956, the Mendes-France government had organized a colloquim at Caen. But neither Gros nor anybody else appears to have anticipated the energy that Chevènement would put into the project, which fitted with his own political position in a syndicalist faction of the Socialist Party.

Between October 1981 and the end of the year, no fewer than 31 three-day meet-

\section{Colloquia galore}

JEAN-Pierre Chevènement's most memorable achievement may have been his decision to hold a series of regional colloquia (assizes) at which members of the scientific community could voice their aspirations and discontents. Certainly, he has many imitators.

Beginning this year, the ministry of research and technology plans a series of such colloquia dealing with particular fields of research. The first of them, this January, launched "cogniscience" on the psychology and neurobiology communities. Earlier

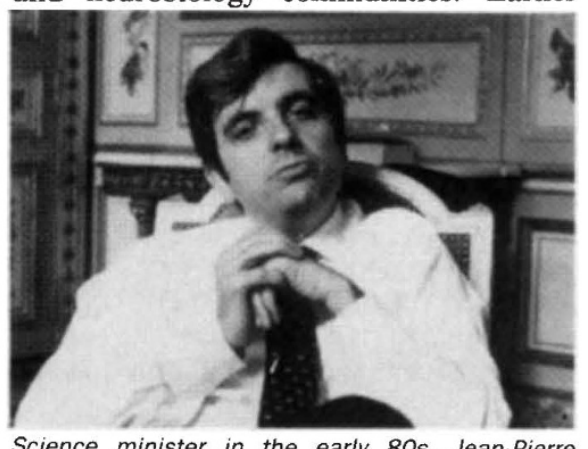

Science minister in the early 80 s, Jean-Pierre Chevènement

this month at Strasbourg, there was a similar meeting on planet Earth.

The objectives are several - to improve coordination in continuing fields of study, to plan how to exploit emerging areas (order and chaos, for example) and to explore the relations between academic studies and their application.

But the Ministry of National Education has now joined in, with a colloquiun at the Sorbonne last month which gave the minister, M. Lionel Jospin, the opportunity to repeat Allègre's slogan "Diversity means equality" (see page 133).

ings were organised throughout France, culminating in a four-day meeting in Paris in mid-January 1982. It is estimated that some 25,000 people took part in the regional meetings.

The organization of this gigantic consultation was carried out by a committee under François Gros, with Dr Philippe Lazar (then the president of the scientific council of INSERM, now its directorgeneral) as vice-president and rapporteur. Even now, Lazar vividly recalls how, after nearly a year's intensive work on the organization of the colloquia, he had been looking forward to a vacation. Instead, Chevènement asked him to move to INSERM right away.

Among others, one of the emergent themes was the importance of research as a means of bridging the economic gap between rich and poor countries, now embodied in the great emphasis in French research on the problems of tropical agriculture. But the overarching theme was that science belongs to the people and is a part of the general culture. 